\title{
Building sustainable food systems in a single bottom-line context: Lessons from SEED Wayne, Wayne State University
}

\author{
Kameshwari Pothukuchi, Department of Urban Studies and Planning, Wayne State University
}

Submitted 12 December 2011 / Revised 21 February and 10 April 2012 / Accepted 10 April 2012 / Published online 8 June 2012

Citation: Pothukuchi, K. (2012). Building sustainable food systems in a single bottom-line context: Lessons from SEED Wayne, Wayne State University. Journal of Agriculture, Food Systems, and Community Development, 2(3), 103-119. http://dx.doi.org/10.5304/jafscd.2012.023.011

Copyright (C) 2012 by New Leaf Associates, Inc.

\begin{abstract}
This paper discusses a four-year effort, embodied in an initiative called SEED Wayne, to implement a university-community sustainable food system collaboration involving multiple activities in campus and neighborhood settings, which also coincided with moves to institutionalize elements of the program as part of the university's core functions of education, research, engagement, and operations. The paper documents the many ways in which activities have indeed successfully integrated across the university's functions and discusses factors accounting for this integration. However, attempts to institutionalize the farmers' market as a university operation have encountered barriers heightened by an increasing focus on the single economic bottom line brought on by public funding cutbacks, which exacerbates the cleavage between functions considered academic -
\end{abstract}

Kameshwari Pothukuchi is Associate Professor, Department of Urban Studies and Planning; Wayne State University; Detroit, MI 48202 USA; +1-313-577-4296; k.pothukuchi@,wayne.edu. She is also director of SEED Wayne. teaching and research - and those related to engagement and operations. The university's vast bureaucracy also challenges innovative approaches to an integrative sustainability agenda. The paper discusses the implications of these challenges and offers recommendations to others wishing to embark on a similar initiative.

\section{Keywords}

SEED Wayne, sustainable food systems, university-community partnerships, university sustainability programs

\section{Introduction}

Institutions of higher learning today embark on a sustainability journey for a host of reasons and in a dizzying variety of ways. The possibility of achieving cost savings, revenues from related courses and programs, status and prestige, student learning and leadership on a topic of great societal significance, and increasing endowments and funding support make it an attractive agenda to adopt, even if it is not without risks and challenges. This paper discusses a four-year effort called 
SEED Wayne to build sustainable food systems (SFS) at an inner-city university — Wayne State University - and in surrounding Detroit neighborhoods by integrating related activities in the core functions of the university: education, research, engagement, and campus operations. A faculty-led initiative, it also embodies close collaboration with students and administrators, and embraces community-based collaborations as indispensable to the development of sustainable food systems on campus. Since its inception, the program, housed in the Department of Urban Studies and Planning, has linked to the university's four functions in diverse ways and developed competent student leadership on a host of topics. These linkages highlight the critical importance of the topic, its timeliness, the ease with which groups from different disciplinary backgrounds and locations at the university can connect to activities, and the gains these groups experience from the linkages. From this experience, it is fair to say that SFS activities excite the civic imaginations of university members and leaders, who work to extend the reach of activities and enable their success.

Nevertheless, the program has also experienced specific constraints to fully institutionalizing an SFS agenda. While these constraints affect the entire program, they are particularly pronounced in attempts to institutionalize the campus farmers' market - the program's most complex initiative - as a university operation, albeit as one defined as a social enterprise rather than a business operation more typical of the university's structure. To conceptualize a transition from a farmers' market that started life as a faculty-led action research project to a university-run social enterprise that also integrates research, education, and engagement, is to ask basic questions of the university's ability to integrate sustainability within its current organization.

As this study shows, a fully integrated SFS agenda demands at least three things of universities: commitment to multiple bottom lines; interlinking of core academic and nonacademic functions, with special attention to how the university conducts its daily food business consistent with a sustainability mission; and a responsive bureaucracy that allows novel approaches to flourish. Despite the successes experienced by the program, these dimensions are as yet underdeveloped at Wayne State.

The paper is structured in four parts. The first lays out key arguments for university leadership in SFS to set the stage for a discussion of WSU's status relative to them. The second describes how SEED Wayne's activities are integrated into the core functions of the university. The third section discusses factors that facilitate as well as challenge moves to institutionalize SFS, while a concluding section draws general lessons from this experience and offers recommendations for colleagues and students at other universities contemplating similar activities.

\section{University Leadership in Sustainable Food Systems: The Arguments}

The social, ecological, and economic problems posed by the industrial food system - particularly to inner-city and impoverished communities - are many, and need not be repeated here (see, for example, the American Planning Association's Policy Guide on Community and Regional Food Planning, 2007, and Pothukuchi, 2011, for a summary of Detroit's food system assets and liabilities). SEED Wayne's arguments for Wayne State University's leadership in building SFS are based on the following rationales: one, as a civic institution with an urban mission, the university has a responsibility to the surrounding community and region; two, as one of Detroit's larger employers it is endowed with significant human and material resources with which to leverage broader gains; and three, the university's engagement in SFS has the potential to address a not-insignificant portion of the food needs that exist in its neighborhood while creating one path (among many) for a resurgence of a city in decline.

Many colleges and universities are charting a course for a more or less systematic approach to SFS, as evidenced by 166 such projects documented on the Farm to College website (n.d.). Nonetheless, it is fair to note that few universities, if any, embrace SFS spanning a full spectrum of possible roles and linkages, including by seamlessly integrating into research, teaching, engagement, 
and operations. More critically, universities' embrace of their broader civic responsibilities seems even less likely given a widespread and increasingly private and business orientation and adoption of strict bottom-line imperatives in all key functions. Given the paper's analysis, these arguments are worth reviewing briefly.

\section{Universities' Civic Missions}

Universities serve functions besides training young people for future employment, helping them develop their potential, and replicating society and culture; they also have roles in transforming society and creating more just arrangements (Bowen, 1997; Boyer, 1996; Orr, 1991; White 2000). Cutbacks in public spending, however, drive them to cut services, raise tuition, outsource basic services such as food and housing, and engage in more distance education (Schumpeter, 2011; Kaysen, 2012; Kelderman, 2009). This has led to renewed handwringing about the ramifications of increasing privatization to the civic mission of the university (Aronowitz, 2000; Aronowitz \& Giroux, 2000; Carnegie Foundation for the Advancement of Teaching and CIRCLE, 2006; Colby, Beaumont, Ehrlich, \& Corngold, 2007; Giroux \& Giroux, 2004; Kelderman, 2009; The National Task Force on Civic Learning and Democratic Engagement, 2012; Newman, Couturier, \& Scurry, 2004).

Critics of privatization call for defending higher education both as a public good and an autonomous arena for the development of critical, productive, and democratically inclined citizens. Fearing that higher education was increasingly becoming a private benefit rather than a public good, in 1996, Boyer called for a robust scholarship of engagement, in which the academy "must become a more vigorous partner in the search for answers to our most pressing social, civic, economic, and moral problems" (p. 17). He warned that "our great universities simply cannot afford to remain islands of affluence, self-importance, and horticultural beauty in seas of squalor, violence and despair" (p. 32). This plea is as urgent today as ever for our university, located as it is in inner-city Detroit.

To be sure, university leaders and civic-minded groups are scarcely immune to such calls (Boyte \&
Hollander, 1999; Carnegie Foundation for the Advancement of Teaching and CIRCLE, 2006; Colby et al 2007; London, 2002; The National Task Force on Civic Learning and Democratic Engagement, 2012). In early 2012, U.S. Secretary of Education Arne Duncan convened a national conversation, "For Democracy's Future: Education Reclaims Our Civic Mission," on the importance of educating students for informed and engaged citizenship (U.S. Department of Education, 2012). Noting the need for collaboration with other countries to develop sustainable sources of energy, reduce poverty and disease, and curb air pollution and global warming, the secretary concluded, "the U.S. cannot meet those global challenges, both here in our local communities or abroad, without dramatically improving the quality and breadth of civic learning and democratic engagement" (para. 13).

In a similar vein, in A Crucible Moment, the National Task Force on Civic Learning and Democratic Engagement asserts that "full civic literacies cannot be garnered only by studying books; democratic knowledge and capabilities also are honed through hands-on, face-to-face, active engagement in the midst of differing perspectives about how to address common problems that affect the wellbeing of the nation and the world" (2012, p. 3). It further calls on educators and public leaders to advance a twenty-first century vision of college learning that goes beyond community service to foster democratic engagement with others across differences to collectively solve public problems, develop reciprocal partnerships, and analyze systemic causes of a given issue.

Campus sustainability initiatives inherently draw on the civic responsibility of public universities in order to confront the real challenges challenges which cross disciplinary boundaries, create and reflect social divides, and offer the possibility of multiple solutions - facing local communities and the world. Although many urban universities have enacted civic engagement into their missions (see, for example, Coalition of Urban and Metropolitan Universities, n.d.; and Coalition of Urban Serving Universities, n.d.), a systematic approach to sustainability in these missions is largely absent. 
Universities as Leaders in Sustainable Development

Sustainable development is commonly understood as an approach to meeting the needs of the present without compromising the ability of future generations to meet their own needs (World Commission on Environment and Development [WCED], 1987). Sustainability goals also embrace the triple bottom lines of economic vitality, social equity, and ecological integrity. Beginning with the Stockholm Declaration of 1972, there has been a steady stream of national and international sustainability declarations relevant to higher education (Wright, n.d.). A key moment in framing university roles related to sustainability came in 1990 when university presidents from across the globe agreed that, "Universities educate most of the people who develop and manage society's institutions. For this reason, universities bear profound responsibilities to increase the awareness, knowledge, technologies, and tools to create an environmentally sustainable future" (University Leaders for a Sustainable Future [ULSF], n.d., para. 2).

The leaders discussed the importance of increasing environmental literacy and citizenship, and called for higher education institutions to model environmentally responsible behavior in their daily activities. "By practicing what it preaches, the university can both engage students in understanding the institutional metabolism of materials and activities, and have them actively participate to minimize pollution and waste" (USLF, n.d. para. 3). The resulting Talloires Declaration included actions aimed at increasing awareness of environmentally sustainable development, creating an institutional culture of sustainability, involving stakeholders, educating for environmentally responsible citizenship, collaborating for interdisciplinary approaches, practicing institutional ecology, and broadening service and outreach nationally and internationally.

Experiences with campus sustainability offer many lessons. For example, Moore (2005) offers seven recommendations for a successful initiative, including the need to infuse sustainability in all decisions; promote and practice collaboration; promote and practice transdisciplinarity; focus on personal and social sustainability; and integrate research, service, and teaching. Additional lessons include the importance of encouraging intrauniversity learning and stakeholder dialogue, and clarifying required paradigm shifts (Lidgren, Rodhe, \& Huisingh, 2006). Bosselman (2001) cautions, however, that "a sustainable university needs an open and transparent administration, capable of supporting the necessary changes. At present, administrative structures are not only alien to students, but to some extent, to staff also. They seem to be concerned with the efficient use of resources only, rather than with the needs of the university as a whole" (pp. 174-175). Unfortunately, as this paper witnesses, the current moment of economic crisis and political resistance seems even less auspicious for universities to take a broader view of sustainability.

Subsequent sections offer a case study of how the two core arguments for university engagement with SFS are implicated in its partial integration in one university, but also are experiencing tensions in specific yet not unfamiliar ways. But first, the next section describes SEED Wayne and its many activities bridging campus and community settings through related partnerships. For more context, a basic description of the university may be found at its website. ${ }^{1}$ This discussion and the analysis that follows are informed by SEED Wayne's and university records, and interviews with administrators and colleagues on campus. WSU also has an office of sustainability, a product of a campuswide sustainability task force convened in 2006 but staffed only since $2011 .^{2}$

\section{SEED Wayne, Wayne State University}

Established in 2008, SEED Wayne's genesis lies in a university-community challenge grant awarded by the Ford Motor Company Fund. Prior to this, the university offered no activity related to sustainable food systems. In the weeks preceding the grant submission, the author reached out to several highlevel university administrators overseeing research,

\footnotetext{
${ }^{1}$ See the Wayne State University website at http://wayne.edu/about/

${ }^{2}$ Browse http://livinggreen.wayne.edu/. The office has to date prioritized conservation and materials recovery and outlines few systematic linkages to educational, research or engagement functions.
} 
community engagement, and academics, and to faculty members in the nutrition department and in the engineering and business schools. This process and the author's outreach in the community resulted in letters of partnership from more than 15 campus and community leaders, constituting an important first step in institutionalizing the initiative as a campus-community collaboration. So crucial were these commitments that SEED Wayne was able to open its doors on June 15, 2008, several weeks before the announcement of the Ford award.

Building on existing discourse, SEED Wayne defines sustainability as promoting the four Es: ecological regeneration, economic viability, social equity, and democratic engagement. These are operationalized as follows:

a) increase access to fresh and healthy foods on WSU's campus and in Detroit neighborhoods, with special emphasis on increasing access to low-income campus and community members;

b) link local eaters more closely with locally based sources of food;

c) Increase capacity at various levels, from the individual to the community and region, on key food system issues, such as healthy food preparation with seasonal products, local food production, and food infrastructure and policy development; and,

d) advance community goals in public health, economic development, ecological regeneration, social justice, and democratic decision-making through food system activities on and outside campus.

\section{SEED Wayne's Links to Education, Research, Engagement, and Campus Operations}

SEED Wayne activities are offered in collaboration with diverse campus units and community organizations, and engage campus and community members in different ways. Intentionally cultivating student leadership is also central to all program activities. Beyond specific classroom and research activities that are planned and completed within discrete timeframes of semesters or grant require- ments, SEED Wayne offers several standing activities: three campus vegetable gardens, the WSU Farmers Market (WSUFM), Detroit FRESH (the healthy corner store project), campus composting, and farm to cafeteria (see table 1 in the appendix). Additionally, activities such as the annual farm tour, the annual harvest dinner, and the quarterly newsletter keep participants engaged, informed, and connected, and their contributions recognized.

\section{Linkages to the University's Educational Mission}

Sustainable food systems are integrated into the educational mission of the university through traditional coursework and related projects, independent studies, and interactive learning in co- and extracurricular activities. An annual course on "Cities and Food" offered in the Department of Urban Studies and Planning is open to students from across campus, who are at or above their fourth year of undergraduate study. The course examines impacts on urban areas of the global, industrial food system, and alternatives that are more sustainable, just, and responsive to local communities. It also features a seminar series, "Building a Sustainable Food System in Detroit," in which local food experts discuss specific topics. The seminars are open to the public and are well attended by community members. The course is also officially recognized on campus as a servicelearning option, because of team projects designed in collaboration with community-based partners. For example, in 2011 one team surveyed a sample of 22 stores out of a list of nearly 80 Detroit grocery stores designated as full-service by the Detroit Economic Growth Corporation. Among other things, they found a handful of stores that fell far short of the offerings of a full-service store. Its study was published in the Michigan Citizen, a community newspaper. Fifty-one students graduated from this class between 2008 and 2011.

Class projects with SEED Wayne as client also have been offered in departments such as English, Anthropology, Sociology, Communications, Library Sciences, Engineering, Graphic Arts, and Instructional Technology. Projects included inquiries into food procurement decisions by shoppers at the WSUFM, reasons motivating participation in campus gardens, and salient themes 
for creating SFS messages that are compelling to WSU students. Since 2008, SEED Wayne has helped design projects in nine such classes; additionally, the author has lectured about sustainable food system topics in several more. The author also routinely advises individual-study projects on SFS topics implemented by WSU students and, less often, at the University of Michigan and Michigan State University. Since 2008, the author's contributions to several dozen such studies ranged from comprehensive one-on-one guidance, to quick reviews with suggestions, to responses to questions.

Universitywide lectures by internationally recognized experts in SFS constitute another educational layer. Since 2008, guests included Will Allen, MacArthur Fellow and executive director of Growing Power; Wayne Roberts of the Toronto Food Policy Council; Cecilia Rocha at Ryerson University; and Jerry Kaufman, emeritus professor at University of Wisconsin-Madison. These lectures are widely advertised and receive at least half their attendance from noncampus members.

Attendance in these lectures has ranged from 40 to more than 100. The author and other SEED Wayne representatives also lecture in the region and beyond. In 2011, eight such presentations were made nationally and in the Netherlands, the majority in southeastern Michigan. The quarterly newsletter is e-mailed to more than 2,000 subscribers, and the annual harvest dinner also provides related information and engagement.

Not least, much educational activity occurs through hands-on engagement, with informal conversations and structured workshops at, and research activities on the WSUFM, campus gardens, corner stores, and during the annual farm tour. Structured activities include cooking demonstrations, workshops on agricultural practices, tabling on nutrition and healthy food preparation, and sharing educational materials on a variety of SFS topics. Instructors range from professional and licensed chefs and registered dieticians to student volunteers. Project sites such as gardens and the farmers' market are also destinations for field trips organized by local schools and gardening organizations.
Linkages to the University's Research Mission Constituted as an action research program, all of SEED Wayne's projects involve the collection and analysis of data and preparation of reports for internal use and external dissemination. Additionally, SEED Wayne partners with faculty members across campus on a variety of research topics, including those related to soil and atmospheric pathways of lead and other heavy metals in community gardens, community food assessments, and developing complementary community- and clinically based responses to childhood obesity. Since 2009, the program raised about USD300,000 for these topics - modest by typical university standards, but nonetheless a robust foundation for a novel approach to diverse community-food linkages in a nontraditional university setting. Grants for a similar amount were unsuccessful.

Program sites also have hosted research activities led by students related to the possibility of growing food on the roof of a parking structure, systems analysis of the WSUFM, factors facilitating engagement of neighborhood residents in a community garden started by students, assessing the feasibility of a market delivery initiative, attitudes of suburban church members before and after a guided tour of various Detroit food system sites, and others.

Finally, the author has written research reports for use in policy development and related fundraising by community-based entities such as the Detroit Food Policy Council and the urban agriculture working group. For example, the Detroit Food System Report, 2009-2010, compiles a variety of data and analyses related to Detroit's food system and its community impacts, and offers related policy recommendations.

\section{Linkages to the University's Community Engagement Mission}

Because the university's official engagement mission is effectively an elaboration of its goals related to research and education, SEED Wayne broadens this category considerably through goals related to SFS partnerships. ${ }^{3}$ The last strategic plan adopted

\footnotetext{
${ }^{3}$ The university's official mission statement is available here: http://www.bulletins.wayne.edu/fib/fib2.html\#22177
} 
by the university identifies the importance of "mutually beneficial partnerships with external organizations, supporters, and friends of the University; [enhancing] relationships with [kindergarten through twelfth grade] school systems and community colleges; and expand[ing] opportunities for the university to be a premier destination and venue for diverse cultures to interact in an urban environment." 4

SEED Wayne articulates both an explicit goal to create sustainable food systems through campus-community collaborations, and also defines sustainability as integrally embodying objectives related to social equity and participation. The program formally or informally collaborates with practically all the SFS organizations in the city and several in the region, and serves to connect other university units, including the two units with engagement responsibilities, ${ }^{5}$ to these organizations.

SEED Wayne's educational and research activities on campus and in the community consistently involve community partners. All activities are designed for mutual campus-community benefit, leveraging university resources to create community gains, building on the expertise of community partners to strengthen program offerings, and

(accessed February 15, 2012). On the institution's commitment to the Detroit metro, the statement notes, "first, it uses its metropolitan locale as a setting for basic and applied research and fosters the development of new knowledge of urban physical and social environments; second, it employs its locale as a teaching laboratory and incorporates metropolitan area materials into its curriculum; and third, it brings knowledge to bear to assist and strengthen the metropolitan area. In particular, Wayne State University contributes to the economic revitalization of southeastern Michigan through research programs that develop new technology and teaching programs that educate the citizens who will live and work in the region in the coming years."

${ }^{4}$ http://www.bulletins.wayne.edu/ fib/fib2.html\#18871

${ }^{5}$ One of these units is Community Engagement @Wayne office, housed in the I. D. Reid Honors College. Founded in 2007, it seeks to connect service-learning courses in the university with community partners (see

http://communityengagement.wayne.edu/). The other is the Office for Government and Community Relations, which has few systematic linkages to academic activities (see http://govaffairs.wayne.edu/mission.php). developing community projects to improve food systems knowledge and test the efficacy of related actions. For example, campus gardens receive support in the form of seeds, transplants, and technical assistance from city garden organizations; in turn, market gardeners from across the city sell at the WSUFM under the "Grown in Detroit" label. Similarly, Detroit FRESH collaborates with a local coalition of faith-based organizations to strengthen its outreach component while also contributing to the coalition's goals related to healthy food access within neighborhoods.

\section{Linkages to University Operations}

Although initial conversations with administrators of campus operations met with mixed support, over the last few years resistance has slowly waned, especially from Facilities staff. They have helped gardens expand to new sites, provided loans of tools, developed new water connections for gardens, and dropped off fall leaves with which to cover garden beds. The farmers' market, too, was enthusiastically supported by the vice president for business operations, who, nonetheless, also signaled from the beginning her view that the activity properly belonged within her division. ${ }^{6}$ The farmers' market also has provided an opportunity to educate and engage campus police about community food issues.

AVI Foodsystems, the campus food service contractor since 2002, offered only minimal options for partnership initially, as the director of campus operations seemed less enthusiastic than chefs about local sourcing and buying from the farmers' market. All that changed, however, when the business hired Susan Schmidt as resident director. Schmidt is arguably the region's pioneer in implementing institutional sourcing from individual farmers, due to her experience in a previous job. Under her leadership, AVI purchased more food from local sources, including the WSU farmers'

\footnotetext{
${ }^{6}$ This conditional support caused some frustrations early on given that the market's goals related to accessibility for lowincome populations and preferential support of small-scale farms (through lower stall rentals) could not be achieved by the purely business approach of her unit. She has since left the university.
} 
market and freed the executive chef to offer cooking demos there, sponsored the program's annual harvest dinner in 2009 and 2010, and participated actively in the winter garden and related Earth Week festivities. According to her Harvest Dinner presentation on November 3, 2011, Schmidt credits SEED Wayne as one of the reasons that motivated her to join WSU.

To conclude this section, SEED Wayne not only connects to the university's functions and trifold mission in multiple ways, but also greatly extends these by integrating objectives related to SFS. Administrators, colleagues, and students support these objectives with their time and influence. Nonetheless, university support for SEED Wayne activities in meaningful and ongoing ways, either directly through financial contributions, or indirectly through release time for the faculty coordinator, for example, are as yet absent. Perhaps more critically for the future of the program, SEED Wayne finds itself isolated in its efforts to make and maintain links among campus functions and between campus and community goals absent a broader institutional framework that recognizes the importance of these links for sustainability.

\section{Factors Facilitating Integration in the University}

Many factors account for the program's ability to suffuse SFS issues into the institution's core functions. Indeed, it is fair to note that these factors map well onto the rationales for the civic responsibilities of the university discussed earlier. First, SEED Wayne links to the university's goals and interests in ways that cause it to attract support enthusiastic support, in some cases - from students, faculty, alumni, and administrators. The program's projects engage students in experiential learning activities in ways that help students strengthen their knowledge and analytic and creative skills on a significant topic, build their social networks, increase their commitment to the institution, cause them to volunteer in the community, and spend more time on what's mostly a commuter campus.

SEED Wayne also offers multidisciplinary research opportunities on a variety of topics such as those listed earlier. Campus members - faculty, students, and administrators - who are champions of the program take seriously the university serving as a locus of innovation, and leverage their positions to increase the program's visibility and build new connections (McInnis, 2009; Wayne State University, Division of Research, 2010). The community linkages forged by SEED Wayne also have both practical and symbolic value for a university that prides itself on its urban mission. No less important is the positive press and attention garnered by SEED Wayne's accomplishments on campus and in the community. ${ }^{7}$

Second, SEED Wayne's numerous achievements over a scant four years, admittedly, are also enabled by the timely and comprehensive nature of the topic of SFS, as concerns related to obesity, the local food economy, vacant land, and access to healthy foods loom large in Detroit. University leaders believe that the university stands to make a significant contribution on these issues. It also did not hurt the program's visibility when a year or so after our campus gardens and farmers' market were established, the White House vegetable garden was developed by first lady Michelle Obama, and the pilot farmers' market was offered near the White House.

Third, also driving support by some administrators were the plodding efforts by a campuswide sustainability committee established in 2006 at the behest of a member of the university's board of governors, who wanted the university to take leadership on sustainability issues. The committee met several times but was unable to accomplish much given extremely stretched faculty schedules and the lack of resources to staff it for most of its existence. In a meeting to seek support for SEED Wayne, the VP for research averred that the initiative for sustainability is appropriately driven by faculty members' research interests and connections to students, rather than by a resource-starved campus committee (H. Ratner, vice president for research, personal communication, May 13, 2008).

\footnotetext{
${ }^{7}$ For example, Today@Wayne is an e-zine emailed daily to all WSU employees. The WSU Farmers Market and SEED Wayne have been featured on several occasions, including October 4 and November 2, 2011, and April 9 and May 17, 2012. See also McInnis (2009).
} 
Table 2. SNAP and DUFB ${ }^{a}$ at the WSU Farmers Market

\begin{tabular}{lccc}
\hline Year & $\begin{array}{c}\text { Average number } \\
\text { of SNAP customers } \\
\text { per day }\end{array}$ & $\begin{array}{c}\text { Average SNAP } \\
\text { sales per day }\end{array}$ & $\begin{array}{c}\text { Total SNAP } \\
\text { spending for year } \\
\text { (DUFB in parentheses) }\end{array}$ \\
\hline 2009 & 32 & USD219 & USD5,032 \\
\hline 2010 & 39 & USD 398 & USD9,947 $(\$ 6,875)$ \\
\hline 2011 & 50 & USD 582 & USD12,215 $(\$ 11,782)$ \\
\hline
\end{tabular}

Estimated total sales in 2011: USD250,000

a The Double Up Food Bucks (DUFB) program matches SNAP spending to support the purchase of Michigan-grown fruits and vegetables.

Finally, SEED Wayne links to the university's functions and participants in versatile and convenient ways, without making unreasonable demands of partnering units — and, indeed, by contributing to their revenues whenever possible - and tailoring the program's participation to their needs and priorities. Growing food on campus, linking gardens and farms with cafeterias, and establishing farmers' markets and healthy corner store projects provide avenues for students and colleagues to participate in accessible ways in terms of skills needed, time commitment, and relative autonomy of implementation. The market contributes revenue to WSU Business Operations by paying for tent rentals, labor for set up and takedown, and vendor parking. Gardeners and Detroit FRESH volunteers come from a variety of disciplines and interests, can be at different levels of study or status (our allotment garden participants, for example, include a college dean, although most are undergraduate students), and are able to contribute effort when their schedules allow. Thus, SEED Wayne supports and advances the university's civic functions, while helping members and partnering units reach beyond usual silo boundaries to link to program activities.

\section{Barriers to Institutionalizing the WSU Farmers Market}

Despite these accomplishments, however, an argument can be made that the institution's growing focus on the single economic bottom line and its complex bureaucracy pose continuing challenges for institutionalizing the farmers' market (WSUFM) as a university operation. The former especially fosters tunnel vision related to the university's mission and reinforces the split between what are considered to be academic functions of research and teaching on the one hand, and nonacademic ones of community engagement and campus operations on the other. Such a split further challenges efforts to create a space that upholds multiple bottom lines of and integrative approaches to sustainability; more concretely, it makes it hard to uphold the equity, health, and localism-oriented values underlying the WSUFM's structure and operations. It is conceivable that these barriers can be chipped away through negotiations with individual administrators since similar negotiations have borne fruit thus far. However, the farmers' market experience suggests that a more thorough transformation of the university's commitments and practices will likely be needed to institutionalize SFS more fully into the institution's fabric.

The rationales for institutionalizing the WSUFM as a university operation are twofold: one, as a complex operation with many moving parts, it cannot indefinitely be sustained as an action research project within an academic program with zero support staff and implemented by a full-time university faculty member; and two, the university is in a better position to capitalize long-term on the market's research and successes to date. Over the course of four years, the WSUFM project has accomplished several things: It delivered, in convenient ways and at affordable rates, fresh and locally produced foods to campus and nearby community members; incorporated government nutrition programs to serve impoverished members; entered into mutually beneficial community partnerships; provided a viable market for participating vendors; developed a range of educational and social activities for diverse audiences; and supported the research activities of students and faculty colleagues. It also supported several students as employees and more as volunteers, all of whom gained valuable experience. Only a modest subsidy was needed to cover market manage- 
ment costs. Armed with these findings, the author has made several overtures to administrators without much success to date - to explore a better institutional location for the market and ongoing oversight in a way that respects its underlying values.

\section{The Single Bottom Line of the University vs. the Multiple Bottom Lines of SFS}

As mentioned earlier, sustainability in SEED Wayne means striving for the bottom lines represented by the four Es. Despite efforts in the direction of energy and materials conservation, the university has not formally defined what leadership on sustainability means for the institution's core purposes and its relationships with the outside world.

The university's business operations unit (BusOps) seems a logical place to explore an optimal administrative location for the WSUFM. This office has jurisdiction over the university's business and nonacademic revenue-generating activities, such as the conference center, parking, and leases to campus-based vendors, and it manages credit and debit card operations. The problems with BusOps as a location for the farmers' market relate most pointedly to the mismatch of its single, economic bottom line, with the market's multiple bottom line values. Many, if not most, of BusOps responsibilities are directed to be fully supported by revenues, with reduced reliance on general fund support. ${ }^{8}$ This has put significant pressure on the unit to shrink costs and continually raise revenues and fees. ${ }^{9}$

\footnotetext{
${ }^{8}$ For FY 2011 auxiliary operations budget, see Wayne State University (2010b). Auxiliary operations are self-sustaining, that is, supported entirely through their revenues, except for campus housing.

${ }^{9}$ See Wayne State University's Auxiliary Budgets Summary (2010b); note especially parking fee increases recommended for FY 2011, and those proposed for 2012 and beyond (p. 200), and increases in residence hall room and board charges (p. 183). A parking rate hike instituted in 2007 without consultation with faculty or students caused great consternation regarding the decision's seeming disconnect with academic life. See http://webcache.googleusercontent.com/ search?q=cache:http:// faculty.law.wayne.edu/mcintyre/ budget/PDF Files/Minutes/memo-parking fee increase.pdf
}

Two, although it operates within the Equal Opportunity and Affirmative Action rubric of public institutions, BusOps has little stated preferential commitment to, nor much practical experience engaging with, locally owned, small-scale, and independent operations, or with those that are minority- or woman-owned. Such businesses are important to the mission of the farmers' market in creating a local and equitable food economy. Almost all businesses located on campus are corporate chain stores with easily recognized brand names. These corporations are adept at doing business with universities and can withstand the university's requirements, conditions, and payment schedules in ways that a smaller business with a lower capacity for processing paperwork or tighter cash flow might not. ${ }^{10}$ Furthermore, BusOps has little direct experience working with farmers, as all campus food service operations are outsourced to AVI Foodsystems. Relatedly, the university has zero experience with government nutrition programs such as food stamps (also called SNAP, Supplemental Nutrition Assistance Program).

These characteristics offer little confidence related to the unit's ability to accommodate the needs and constraints of small businesses, let alone small farmers, whose ability to participate any given week is tenuous at best, easily disrupted by a vehicle breakdown or a storm that laid waste to harvests. Preferentially charging Detroit growers lower rent, keeping the dozens of would-be dessert vendors who are willing to pay full rent at bay, discounting rent when a small-scale farmer experiences a particularly bad day, all are alien to the standard operating practice of the institution. Cultivating ongoing relationships with community partners (vendors as well as program partners) in the context of a mutually beneficial sustainability

\footnotetext{
10 The challenges faced by smaller firms doing business with university members are many. For example, consistent with its mission, SEED Wayne attempts to give printing business to locally owned, small and independent print shops. Such shops typically prefer up-front payment, which is feasible for smaller amounts. While they are not unwilling to accept larger purchase orders, owners complain bitterly about the length of time payments typically take and the effort involved in chasing payments down.
} 
goal is also not part of the institutional ethic, per se.

Four, although BusOps occasionally seeks research advice from faculty members on its operations, linking systematically to the academic function of the university and building student leadership are not intrinsic to its mission, while these are for SEED Wayne. Thus, the unit has neither the capacity to internalize the multiple bottom line objectives of sustainability nor has the university created a framework for supporting a sustainability mandate within which it can operate. It must be noted that following significant shortfalls of state funding, particularly since the 2008 recession, the university has restructured budgets, shed hundreds of employees, and put into place other efficiencies to save money. ${ }^{11}$

Although the focus thus far has been on the mismatch between the values and everyday operations of SEED Wayne and BusOps in particular, the fact is that few, if any, units exist that offer an exception to the above arguments. Of the two community engagement units, one is entirely academic in orientation - that is, without links to campus operations, while the other is entirely nonacademic and serves as the community relations arm of the administration.

Funding cuts in state aid experienced by the university are dramatic indeed: in FY 2011, the state's per-student appropriations suffered a body blow, slashed as they were by 71 percent from USD25,197 in FY 2009 (Jen \& Bowerman, 2011). As the public, taxpayer-funded share of the university's budget shrinks, the university is forced to support its operations increasingly through private sources, cut services considered peripheral to its

\footnotetext{
11 "Since 2002, the university has implemented permanent cuts in operating expenses of more than USD50 million through initiatives such as hiring and salary freezes, the streamlining of operations and strategic program realignments geared to recent workforce development trends. Since 2006 WSU has saved an additional USD24.6 million through decreased expenditures for utilities, negotiated health care benefits, more efficient purchasing and other initiatives" (Wayne State University, 2010a). See also auxiliary operations budget for FY 2011 reported in an earlier footnote (Wayne State University, 2010b).
}

core academic mission, and raise student tuition. ${ }^{12}$ It would be naive to expect that forces that cause it to move toward an increasingly privatized model of funding would be hospitable to civic goals such as social equity, ecological stewardship, and local economic development that may, at least initially, impose additional dollar costs. All this is not to imply that institutionalization in a way that endorses the core values of the WSUFM is impossible, nor have all possible avenues been exhausted. It is, rather, to point to the even greater need for transformational leadership than in more stable times.

\section{Bureaucratic Structures in College and University Challenge Market Operations}

Currently, all aspects of WSUFM's operation are managed by SEED Wayne, itself housed in the Department of Urban Studies and Planning. SEED Wayne recruits vendors, enters into contracts with them on behalf of the university, manages market operations including the SNAP transactions, and offers educational and other programming in collaboration with campus and community partners. SEED Wayne also administers the Double Up Food Bucks (DUFB) program, which matches SNAP spending to support the purchase of Michigan-grown fruits and vegetables.

SNAP is administered at the farmers' market through a partnership with Eastern Market Corporation, a nonprofit that hosts the region's largest produce wholesale market and a large Saturday farmers' market just southeast of the

\footnotetext{
${ }^{12}$ Both the tuition rate and its share of the budget went up sharply over the last decade. In FY 2001, state funds represented 63 percent of the budget, with student tuition representing 28 percent. In FY 2012, the respective shares nearly reversed, with tuition representing 60 percent of the budget (Wayne State University, 2011, p. 4). In 2010, Wayne State University Board of Governors voted to increase tuition for resident undergraduate students by 4.4 percent and another 6.9 in 2011 (Wayne State University, 2010b, 2011). Nonetheless, according to the faculty union, administrators received raises at higher rates than did faculty and staff, a move more typical of private corporate practice. Vice presidents received pay increases, for example, that averaged 4.5 percent, while faculty and staff received an across-the-board raise of 2 percent, with smaller distributions of merit raises (Parrish, 2011).
} 
university. When SNAP dollars are debited at the WSUFM (from the Michigan Bridge Card) in return for tokens to be spent at the market, the debited funds are automatically deposited into an account managed by the Eastern Market. At the end of each month, receipts for tokens redeemed from farmers are handed to the organization, which then turns around payments to vendors within one week. Contrast this with the university's typical payment protocol of four to six weeks, which most vendors could not afford. This is just one challenge of many of trying to integrate the farmers' market into the university's bureaucratically organized operations. Accepting SNAP at the WSUFM, however, is indispensable to making it accessible to low-income customers, including students and other community members.

Bureaucracy is a fact of life at large universities: Standardized procedures allow the efficient and consistent processing of transactions regardless of their origin. Novel requests impose demands that are resisted by the bureaucracy and therefore pose additional burdens on faculty members who undertake sustainability initiatives. For example, requests to the college to set up an account separate from research funds to receive market revenues, to fund a student-led activity such as a market-delivery project or a customer incentives initiative, and to reward market volunteers with a free lunch at the market (to be paid for from the program budget), all challenged the college's usual procedures and required many memos with extensive explanations, frustrating even the most basic of tasks. In this context, the ability to outsource SNAP-related financial processing to Eastern Market was a great relief, even if such outsourcing creates its own challenges that are invisible to the college.

Of course, exploring a more optimal institutional location for the market and a better system of management than that led by a full-time faculty member raises other questions and underscores the urgent need for building capacity within the institution for a broader sustainability agenda: Who should lead the farmers' market? Where will the subsidy — modest though it may be — for market management come from on a sustained basis? What mechanisms will be developed for seeking ongoing input from the various constituencies with interests in the market, for decision-making that balances emerging interests with the market's original sustainability goals and values, and for building a broad-based ownership within the university? There are no easy answers to these questions at the moment, although conversations with administrators across campus have generated some exploratory ideas. One such idea is the possibility of a new high-level "innovations" unit that would help programs avoid the barriers reported here while benefiting from mutual synergies, flexibility, and institutional leadership.

\section{Conclusion and Initial Recommendations}

This case study shows that even urban universities without a base in agricultural activities typical of land-grant agricultural schools nonetheless are able to support a variety of sustainable food system activities, including campus-based production. Furthermore, it is possible to integrate sustainable food system activities into all the university's core functions - teaching, research, engagement, and campus operations - even within a context of overall retrenchment, and in so doing, offer yet another way for the university to manifest civic leadership. In this regard, SEED Wayne's successes redound to the institution's credit. Nonetheless, challenges exist due to budgetary forces that push the university away from a civic identification and toward more privatized agendas and sources of support, and reinforce a cleaving of its purposes, such that those defined as academic receive institutional support while others sustain themselves through their own revenues. Thus even as the potential role of the public university to advance sustainability is becoming clearer, the university is becoming more constrained in its ability to act.

It is not impossible to envision the carving of special space within the university, one that is sympathetic to and able to accommodate the multiple sustainability bottom lines of the program and its integrative approaches. Nonetheless, such a unit would only serve to spotlight the more basic barriers within the institution to transform itself to more fully implement a broad-based sustainability agenda that cuts across all functions. Embracing energy and resource efficiency, for example, is 
arguably an easier sustainability task. Preferentially supporting small, local agri-food and other businesses while also building their capacity to do business with the university, and supporting other social equity goals, on the other hand, asks more of the privatizing university than it can offer in an era of besieged budgets and self-supporting operations.

What is to be done? In the short term, the program would be helped by a high-level office transcending individual colleges, that is - that spans various functions defined as academic and nonacademic, collaborates closely with faculty members and students with sustainability interests, and embraces the multiple bottom-line values of sustainability. Initially such an office would need to be supported by general funds but with a mandate to raise external support; it would need to create administrative procedures that short-circuit the current bureaucratic rabbit-hole to support innovative activities and partner with small-scale and local businesses. Over the longer term, there is no substitute for the development of a universitywide strategic sustainability agenda that carefully addresses the public university's civic purposes, aligns resources and activities accordingly, and involves campus and community stakeholders.

Because this program's efforts to institutionalize SFS are still ongoing, recommendations to leaders in other universities are necessarily tentative, and draw from the successes reported herein:

1. Use the possibility of external grant funding for SFS activities to build formal and informal support among diverse campus constituencies: administrators, faculty, student leaders. This process can create momentum even if initial fundraising efforts are unsuccessful.

2. Persist in approaches to integrate SFS into all the core functions of the university (teaching, research, engagement, and operations) even if linkages to one or two functions are stronger to begin with.

3. Support related initiatives suggested or led by students and colleagues or by community members in ways that incrementally expand the scope of SFS goals. Such support is crucial to growing an SFS commu- nity and identifying fresh directions and related leadership.

4. Use SFS educational and research activities to create mutual campus-community benefits, including by tapping into local expertise for university-based courses and research, opening up courses - even if partially - to community members to promote co-learning and dialogue, and service-learning projects designed to answer SFS questions that are locally relevant.

5. Facilitate campus and community partnerships by developing operational frameworks that enable widespread participation, serve mutual organizational interests, and implement cost-sharing to the extent possible.

Campus sustainability initiatives are hard to implement in the best of times. While university administrators may currently perceive few degrees of freedom to operate, the time is also ripe for creative leadership.

\section{References}

American Planning Association. (2007). Policy guide on community and regional food planning. Retrieved from http://www.planning.org/policy/guides/adopted/ food.htm

Aronowitz, S. (2000). The knowledge factory: Dismantling the corporate university and creating true higher learning. Boston: Beacon Press.

Aronowitz, S., \& Giroux, H. A. (2000). The corporate university and the politics of education. The Educational Forum, 64(4), 332-339. http://dx.doi.org/10.1080/00131720008984778

Bosselmann, K. (2001). University and sustainability: Compatible agendas? Educational Philosophy and Theory, 33(2),167-185. http://dx.doi.org/10.1111/ j.1469-5812.2001.tb00261.x

Bowen, H. R. (1997). Investment in learning: The individual and social value of American higher education. Baltimore, Maryland: The Johns Hopkins University Press.

Boyer, E. L. (1996). The scholarship of engagement. Journal of Public Service and Outreach, 1(1), 11-20.

Boyte, H., \& Hollander, E. (1999). Wingspread Declaration on renewing the civic mission of the American research university. Boston, Massachusetts: Campus Contract. 
Retrieved from http://www.compact.org/wpcontent/uploads/2009/04/wingspread declaration. pdf

Carnegie Foundation for the Advancement of Teaching and CIRCLE (Center for Information and Research on Civic Learning and Engagement). (2006, February). Higher education: Civic mission and civic effects. Stanford, California and College Park, Maryland: Authors.

Coalition of Urban and Metropolitan Universities. (n.d.). About CUMU. Retrieved December 7, 2011, from http://www.cumuonline.org/about.aspx

Coalition of Urban Serving Universities. (n.d.). Retrieved December 7, 2011, from http://www.usucoalition.org/

Colby, A., Beaumont, E., Ehrlich, T., \& Corngold, J. (2007). Educating for democracy: Preparing undergraduates for responsible political engagement. San Francisco: Jossey-Bass.

Farm to College. (n.d.). Program profiles. Retrieved December 7, 2011, from http://www.farmtocollege.org/survey\#profiles

Giroux, H., \& Giroux, S. S. (2004). Take back higher education: Race, youth, and the crisis of democracy in the post civil rights era. New York: Palgrave MacMillan.

Jen, K. I., \& Bowerman, B. (2011). Fiscal year 2011-2012 bigher education appropriations report. A report to the House and Senate Appropriations Subcommittees on Higher Education (State of Michigan). Retrieved from http://www.house.mi.gov/hfa/PDFs/ hiedrpt2012.pdf

Kaysen, R. (2012, January 24). Public college, private dorm. New York Times, page B1.

Kelderman, E. (2009, May 1). Public colleges consider privatization as a cure for the common recession. The Chronicle of Higher Education. http://chronicle.com/article/Public-CollegesConsider/44370/

Lidgren, A., Rodhe, H., \& Huisingh, D. (2006). A systemic approach to incorporate sustainability into university courses and curricula. Journal of Cleaner Production, 14, 797-809.

London, S. (2002). The civic mission of higher education: From outreach to engagement. Dayton, Ohio: Kettering Foundation. Retrieved from http://www.scottlondon.com/reports/ seminar2001.pdf
McInnis, D. (2009). Growing Detroit: SEED Wayne is giving a boost to the city's emerging agriculture movement. Wayne State University Alumni Magazine. Retrieved from http://www.alumni.wayne.edu/ uploaded pics/pdf/pdf-20091009114750.pdf

Moore, J. (2005). Seven recommendations for creating sustainability education at the university. International Journal of Sustainability in Higher Education, 6(4), 326-39. http://dx.doi.org/10.1108/14676370510623829

National Task Force on Civic Learning and Democratic Engagement, The. (2012). A crucible moment: College learning and democracy's future. Retrieved from http://www.civiclearning.org/SupportDocs/ Crucible_508F.pdf

Newman, F., Couturier, L., \& Scurry, J. (2004). The future of higher education: Rhetoric, reality, and the risks of the market. San Francisco: Jossey-Bass.

Orr, D. (1991). What is education for? Six myths about the foundations of modern education and six new principles to replace them. In Context, 27, 52. http://www.context.org/ICLIB/IC27/Orr.htm

Parrish, C. (2011, April/May). Administrative salaries. AAUP-AFT Newsbriefs. Retrieved from http://www.aaupaft.org/pdf/Newsbriefs/ NB 2011 AprilMay.pdf

Pothukuchi, K. (2011). The Detroit Food System Report, 2009-2010. Detroit: Detroit Food Policy Council. Retrieved from http://www.clas.wayne. edu/multimedia/usercontent/File/SEED/ 2DetFoodReport 2009-10lores.pdf

Schumpeter. (2011, December 10). University challenge [blog post]. The Economist.Retrieved from http://www.economist.com/node/21541398

University Leaders for a Sustainable Future (Association of). (n.d.) About ULSF. Retrieved December 7, 2011, from http://www.ulsf.org/programs talloires history.html

U.S. Department of Education. (2010). Secretary Arne Duncan's Remarks at "For Democracy's Future" Forum at the White House. Retrived from http://www.ed.gov/news/speeches/secretaryarne-duncans-remarks-democracys-future-forumwhite-house

Wayne State University. (2010a, June 23). Wayne State's 4.4 percent tuition increase is offset by strong financial aid packages [press release]. Retrieved from 
http://media.wayne.edu/2010/06/23/waynestates-44-percent-tuition-increase-is

Wayne State University. (2010b). FY 2011 auxiliary budgets summary. Retrieved from http://budget.wayne.edu/Presentation/FY2011 $\%$ 20Auxiliary $\% 20$ Budget $\% 20$ Summary.pdf

Wayne State University. (2011). FY 2012 current funds budget. Retrieved from http://budget.wayne.edu/ MajorPublications/BudgetBook/FY\%202012\%20 Current $\% 20$ Funds $\% 20$ Budget.pdf

Wayne State University, Division of Research. (2010). Homegrown in Detroit. New Science, 18, 28-29.
World Commission on Environment and Development [WCED]. (1987). Our common future._New York: United Nations. Retrieved from http://www.undocuments.net/wced-ocf.htm

White, G. D. (Ed.). (2000). Campus, Inc.: Corporate power in the ivory tower. New York: Prometheus.

Wright, T. S. A. (n.d.). Definitions and frameworks for environmental sustainability in higher education.

Retrieved from

http://www.ulsf.org/pdf/Wright Declarations.pdf 


\section{Appendix}

Table 1. SEED Wayne Activities on Campus and in the Community

\begin{tabular}{|c|c|c|}
\hline Activities on Campus & Campus Participants & Community Partners \\
\hline $\begin{array}{l}\text { Three campus gardens (including } \\
\text { winter production in low tunnels): a } \\
\text { demonstration garden, an allotment } \\
\text { garden, and an experimental garden }\end{array}$ & $\begin{array}{l}\text { - Approximately } 36 \text { students as } \\
\text { volunteers and garden allotees. } \\
\text { - Large events such as build and } \\
\text { takedown get more volunteers. }\end{array}$ & $\begin{array}{l}\text { - Earthworks Urban Farm } \\
\text { - Greening of Detroit } \\
\text { - AVI Foodsystems, Inc. }\end{array}$ \\
\hline $\begin{array}{l}\text { WSU Farmers Market (22 weeks, } \\
\text { June through October) }\end{array}$ & $\begin{array}{l}\text { - } 16 \text { vendors, including } 9 \text { Detroit- } \\
\text { based vendors; } 6 \text { businesses owned } \\
\text { by people of color, including } 4 \text { by } \\
\text { African American individuals or } \\
\text { groups; and } 5 \text { woman-owned } \\
\text { businesses. } \\
\text { - Approximately } 1,000 \text { customers } \\
\text { participate weekly } \\
\text { - Approximately } 12 \text { students as staff } \\
\text { and volunteers over season }\end{array}$ & $\begin{array}{l}\text { - Eastern Market Corporation } \\
\text { (fiduciary agent for SNAP) } \\
\text { - AVI Foodsystems, Inc }\end{array}$ \\
\hline $\begin{array}{l}\text { Composting of kitchen wastes: } \\
\text { Kitchen wastes at campus dining } \\
\text { halls are composted in two } \\
\text { containers, with compost used in } \\
\text { campus gardens. }\end{array}$ & $\begin{array}{l}\text { - Approximately 4-6 students as } \\
\text { volunteers }\end{array}$ & - AVI Foodsystems, Inc \\
\hline
\end{tabular}

\section{Activities in the community}

Detroit FRESH: 18 corner stores, including liquor stores and gas stations. Activities include storebased technical assistance, linkages to produce distributors, and neighborhood outreach. Project also offers neighborhood healthy food fairs in partnership with participating stores.
- Approximately 12 students as staff and volunteers
- Eastern Market Corporation

- Earthworks Urban Farm

- MOSES (coalition of faith-based organizations)

- Gleaners Community Food Bank
4,000 sq. ft. (372 sq. $\mathrm{m}$ ) passive solar greenhouse at Earthworks Urban Farm on Detroit's eastside, for extended-season growing and agricultural entrepreneurship training.

\section{Participation in Detroit Food Policy}

Council and other policy coalitions.
- Student involvement in class or independent study projects designed to benefit Detroit Food Policy Council

\section{Activities with campus and community components}

Farm/Garden to Cafeteria: Garden harvests are given to community programs and/or used in educational activities on campus
- Approximately 6 students as volunteers
- Several community-based organizations
- Earthworks Urban Farm

- Michigan State University Student Organic Farm

(continues) 
Field- and classroom-based educational activities related to SFS, including 'Cities and Food'

Research collaborations with faculty members across campus and community partners
- Varies by semester

- Varies by semester
- Varies: 4-5 students involved as research assistants
- Earthworks Urban Farm

- Greening of Detroit

- Detroit Food Policy Council

- Detroit Economic Growth Corporation

Annual farm tour in which campus and community members visit farms selling at WSUFM and other regional farms

- Approximately 24 students participate in farm tour; $4-5$ farms visited each trip

- Detroit Black Community Food Security Network

- Earthworks Urban Farm

- Eastern Market Corporation

Annual Harvest Dinner with campus and community partners and supporters to celebrate the season's harvests and partnerships
- Between 75 and 100 students,

employees, and community partners - Earthworks Urban Farm participate by invitation
- Detroit Black Community Food Security Network

- Greening of Detroit
Quarterly newsletter sent to campus and community subscribers
- More than 2,000 recipients 